\title{
Nutritional and feeding ecology in Cory's shearwater Calonectris diomedea during breeding
}

\author{
Joan Navarro ${ }^{1, *}$, Jacob González-Solís ${ }^{1}$, Ginés Viscor ${ }^{2}$ \\ ${ }^{1}$ Departament de Biologia Animal (Vertebrats), and ${ }^{2}$ Departament de Fisiologia, Facultat de Biologia, \\ Universitat de Barcelona, Av. Diagonal 645, Barcelona 08028, Spain
}

\begin{abstract}
In birds, parents adjust their feeding behaviour according to breeding duties, which ultimately may lead to seasonal adjustments in nutritional physiology and hematology over the breeding season. Although avian physiology has been widely investigated in captivity, few studies have integrated individual changes in feeding and physiological ecology throughout the breeding season in wild birds. To study relationships between feeding ecology and nutritional ecophysiology in Cory's shearwater Calonectris diomedea, we weighed and took blood samples from 28 males and 19 females during the pre-laying, egg-laying, incubation, hatching and chick-rearing periods of the breeding season. In addition, we fitted 6 birds with geolocators to track their foraging movements throughout the reproductive period. Thus, we examined individual changes in (1) nutritional condition (biochemistry metabolites); (2) oxygen carrying capacity (hematology); and (3) feeding areas and foraging effort (stable isotopes and foraging movements). Geolocators revealed a latitudinal shift in main feeding areas towards more southern and more neritic waters throughout the breeding season, which is consistent with the steady increase in $\delta^{13} \mathrm{C}$ signatures in the blood. Geolocators also showed a decrease in foraging effort from egg-laying to hatching, reflecting the activity decrease associated with incubation duties. Plasma metabolites, body mass and oxygen carrying capacity were associated with temporal changes in nutritional state and foraging effort in relation to recovery after migration, egg formation, fasting shifts during incubation and chick provisioning. This study shows that combining physiological and ecological approaches can help us understand the influence of breeding duties on feeding ecology and nutritional physiology in wild birds.
\end{abstract}

KEY WORDS: Biochemistry $\cdot$ Ecophysiology $\cdot$ Hematology $\cdot$ Foraging ecology $\cdot$ Seabirds

\section{INTRODUCTION}

During reproduction, birds experience seasonal changes in their breeding duties, which impose changes in their energy demands and feeding requirements and ultimately require some physiological adjustments over the whole breeding season. Seasonal changes in the reproductive physiology of domestic birds have been studied in great depth under experimental conditions (Whittow 2000), but captive birds do not experience the environmental challenges faced by free-living birds. This difference can be particularly significant in many petrel species, which developed specialized systems to allow the exploitation of a harsh pelagic environment (Warham 1990, Brooke 2004).
During the pre-laying stage, many petrels have to recover from a long distance migration, defend their territories and copulate. In addition, females need to obtain lipid and protein nutrients to slowly form just one (comparatively large) egg, which can make up to $29 \%$ of the body mass (Grau 1984, Brooke 2004). After egg-laying, petrels have to endure the comparatively longest incubation period in birds, lasting from 45 to $80 \mathrm{~d}$ (Brooke 2004). During the incubation period, petrels combine long fasting stints (average 5 to $20 \mathrm{~d}$ ) with long foraging trips for self-feeding (Brooke 2004). A few days after hatching, parents remain at sea day and night and regularly visit the nest to feed their slow-growing chick over a long chick-rearing period (Warham 1990). With such an arrangement, petrels 
keep a tight annual schedule and many of them need to start molting feathers before the end of the breeding season (Bridge 2006).

How breeding duties can influence the nutrition and feeding requirements of the birds is still poorly known. Seasonal changes in physiological state can be studied by measuring some biochemical and hematological metabolites (Horak et al. 1998, Jenni-Eirmann et al. 2002), but changes in their levels can be difficult to interpret if we do not gather additional information on the breeding duties, flying activity and diet of the birds. For example, uric acid and urea are the end products of protein catabolism, and their increased level in plasma indicates a greater metabolic use of proteins (Jenni-Eiermann \& Jenni 1998, Totzke et al. 1999, Alonso-Álvarez et al. 2002). Thus, elevated uric acid levels can be related to a greater flying effort, which can deplete lipid and glycogen stores (JenniEiermann \& Jenni 1991, Bordel \& Haase 1993, Jenni et al. 2000). Cholesterol and triglycerides in blood are greatly influenced by diet; animal protein rich diets have been related to low cholesterol and triglyceride levels in plasma (Jenni-Eiermann \& Jenni 1998, Totzke et al. 1999, Alonso-Álvarez et al. 2002). Total plasma protein concentration is related to the ingestion of proteins (Jenni-Eiermann \& Jenni 1998). Avian hematocrit has been regarded as an energetic indicator of foraging activity because it relates to the oxygen transport and delivery requirements (Carpenter 1975). Because flight, the main activity during foraging in seabirds, depends on aerobic capacity, oxygen consumption during flight is potentially limited by blood oxygentransport capacity, leading to a relationship between hematocrit and endurance capacity (Morton 1994, Piersma et al. 1996).

In parallel with biochemical and hematological analyses we can currently obtain information on the feeding behaviour and foraging activity of birds during their pelagic trips. Changes in foraging activity can be investigated using tracking instruments, such as geolocators (Navarro \& González-Solís 2007). Seasonal changes in feeding behaviour are increasingly studied through the analysis of stable isotope signatures in blood, since this tissue integrates the isotopic signatures of the prey consumed over the previous few weeks (Forero \& Hobson 2003); stable isotope signatures of nitrogen $\left(\delta^{15} \mathrm{~N}\right)$ indicate trophic level (DeNiro \& Epstein 1981). Furthermore, within marine environments, $\delta^{13} \mathrm{C}$ signatures vary with diet composition, latitudinal changes in feeding areas or changes in offshore-inshore feeding grounds (Hobson et al. 1994, Thompson et al. 2000).

The Cory's shearwater Calonectris diomedea is a particularly appropriate bird species to study temporal variations in physiological parameters during the breeding season. It is large enough to permit repeated sampling of an adequate blood volume to analyse several blood parameters without interfering with normal physiological processes. Moreover, shearwaters are easy to catch and re-catch during the breeding season because they nest in burrows and are relatively unaffected by human handling. Furthermore, carrying small geolocators for tracking their pelagic movements does not affect the normal feeding behaviour of the species (Igual et al. 2005). Despite all these facilities, there is a surprising scarcity of studies on the ecophysiology of petrels.

In the present study, we examined the nutritional and feeding ecology of this free-living seabird throughout the breeding season. More precisely, we simultaneously examined the individual variation in males and females of nutritional condition (plasma chemistry), body mass, blood oxygen-transport carrying capacity (hematocrit and hemoglobin), stable isotope signatures (C and N). In addition, we tracked foraging movements (foraging effort and feeding areas) in the Cory's shearwaters during the pre-laying, egg-laying, incubation, hatching and chick-rearing periods. Our main aims were (1) to gather a better understanding of the relationships between the physiological state and the seasonal changes in feeding activity and breeding duties, (2) to examine whether males and females show different physiological changes throughout the breeding season and whether these differences can be related to changes in their breeding and feeding activities, and (3) to examine potential relationships among the different physiological variables that can help the understanding of seasonal patterns of variation.

\section{MATERIALS AND METHODS}

Study species. The Cory's shearwater is a long-distance migrant and colonial Procellariiform breeding on the northeast Atlantic and Mediterranean islands. The species shows high reproductive investment $(8 \mathrm{mo})$, long incubation (54 d) and chick-rearing (90 d) periods, and a life span of more than 30 yr (Thibault et al. 1997). Birds nest in rock crevices and burrows under rocks or soil. The species is considered an income breeder, since females form the egg mainly from the food consumed during the pre-laying exodus (Warham 1990, Brooke 2004). The 2 members of the pair share the incubation (laying only 1 egg) and chick-rearing tasks. Apart from the incubation period, Cory's shearwaters rarely stay at the breeding colony during the day. Birds return to the nest only at night to swap the incubating partner or for chick provisioning. Diet mainly comprises epipelagic and epimesopelagic fish and squid (see Thibault et al. 1997 for more details), and during 
breeding the parents mainly feed on areas situated hundreds of kilometers from their breeding site (Navarro \& González-Solís 2007). Cory's shearwaters show an appreciable sexual size dimorphism (Thibault et al. 1997). In the study colony, males were $12 \%$ heavier than females (males $=810 \pm 7 \mathrm{~g}( \pm \mathrm{SD})$, females $=$ $710 \pm 15 \mathrm{~g}, \mathrm{~N}=50$ birds per sex) and between 6 and $9 \%$ larger in tarsus, wing and bill length (Gómez-Díaz \& González-Solís 2007).

Fieldwork and sampling procedures. We conducted

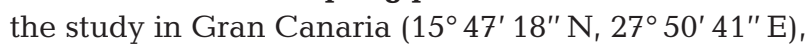
Canary Islands, Spain (Fig. 1), at a breeding colony of about 150 pairs of Cory's shearwaters. To study the temporal variation in foraging strategies, we deployed leg-mounted $10 \mathrm{~g}$ geolocators (Global Location Sensing [GLS] units from British Antarctic Survey, Phillips et al. 2004) on 10 birds in June 2002. After 1 yr (July 2003), we recovered complete data from 6 geolocators. GLS units were equipped with an internal clock, a battery, a photoelectric cell and a microchip and measured the light levels every $60 \mathrm{~s}$, recording the maximum reading within each 10 min interval (full details in Afanasyev 2004). From this information 2 positions per day (one corresponding to midday and the other to midnight) can be inferred with a mean and error $( \pm$ SD) of $186 \pm$ $114 \mathrm{~km}$ (Phillips et al. 2004). To study the temporal variation in blood biochemistry, hematology and stable isotope signatures we could obtain weight and blood samples $(1 \mathrm{ml})$ from 28 males and 19 females from prelaying to chick-rearing at the same breeding colony in

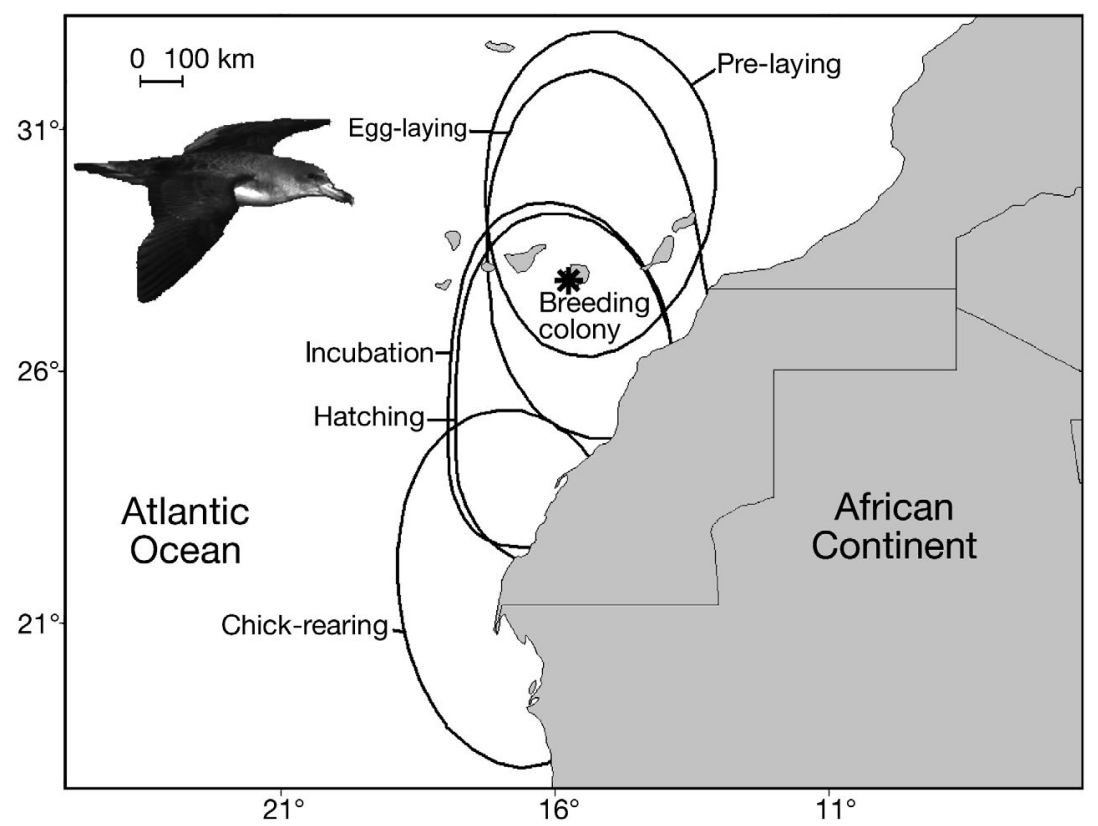

Fig. 1. Calonectris diomedea. Changes in principal foraging grounds (defined as the area encompassing $50 \%$ of the validated positions, see 'Materials and methods; Statistical analyses') of 6 individuals throughout the breeding season
2004. To avoid potential variability of the hydration and fasting state during the incubation bouts on the biochemical analyses, all birds were sampled on the first day after arrival. We sampled blood from the brachial vein at 5 breeding stages: pre-laying, between 20 and $30 \mathrm{~d}$ before laying; egg-laying, between 0 and $10 \mathrm{~d}$ after laying; incubation, between 15 and $20 \mathrm{~d}$ after laying; hatching, between 0 and 5 after hatching; and chick-rearing, between 50 and $60 \mathrm{~d}$ after hatching. Moreover, we measured bill depth, bill depth at nostril, tarsus, culmen and maximum head length to the nearest $\pm 0.1 \mathrm{~mm}$ using a digital calliper. We determined the sex of adult birds using a discriminant function $(D)$ based on morphological measurements. This function was previously developed from measurements and molecular sexing of 154 birds from the same breeding colony (authors' unpubl. data, $95 \%$ effectiveness, $D=1.044 \times$ bill depth $+0.131 \times$ maximum head length -35.803 , Wilk's $\lambda=0.273, \chi^{2}=$ 158.535, $\mathrm{p}<0.001$, positive is male). All birds were measured by the same person (J. Navarro) and the assigned sex was confirmed with respect to the corresponding partner.

Plasma biochemistry, hematology and stable isotope analyses. From the total blood volume extracted in each breeding stage $(1 \mathrm{ml}), 0.9 \mathrm{ml}$ was transferred to a vial containing dry lithium heparin for chemical analysis and $0.1 \mathrm{ml}$ to a vial with $1 \mathrm{ml}$ of absolute ethanol for determination of its isotopic signatures. Heparinised blood samples were stored at 2 to $4^{\circ} \mathrm{C}$ until hematological analyses (within $5 \mathrm{~h}$ of extraction). We determined hematocrit in a $70 \mu \mathrm{l}$ capillary after centrifugation for $8 \mathrm{~min}$ at $12000 \mathrm{rpm}(13000 \times \mathrm{g})$. Hemoglobin was measured photometrically (Clima 3.01, RAL S.A., Spain) after hemolysis in Drabkin's solution (Drabkin \& Austin 1936). The remaining blood $(0.8 \mathrm{ml})$ from the heparisied of the initial $1 \mathrm{ml}$ heparinised blood samples was centrifuged at $5500 \mathrm{rpm}(550 \times \mathrm{g})$ for $10 \mathrm{~min}$ and the plasma was frozen at $-22^{\circ} \mathrm{C}$ and stored up to 2-3 d until analyses (see Bustamante \& Traviani 1994). Plasma triglyceride, cholesterol, total protein, urea and uric acid were determined using a spectrophotometer and commercial kits (Clima 3.01, RAL S.A., Spain).

Blood fixed with absolute ethanol was refrigerated until analyses of stable isotope ratios of nitrogen $\left(\delta^{15} \mathrm{~N}\right)$ and carbon $\left(\delta^{13} \mathrm{C}\right)$. Blood was dried at $60^{\circ} \mathrm{C}$ for $24 \mathrm{~h}$ to remove ethanol and $0.4 \mathrm{mg}$ of homogenized blood was weighed to the nearest $\mu \mathrm{g}$ and placed into a Sn capsule. 
Samples were oxidized with $\mathrm{CuO}$ and $\mathrm{CO}_{3} \mathrm{O}_{4} / \mathrm{Ag}$ at about $900^{\circ} \mathrm{C}$ in a Flash EA 1112 Elemental Analyser coupled to a pyrolyzer TC-EA and a breath bench, through a Conflo III Finnigan MAT interface. $\mathrm{NO}_{\mathrm{x}}$ was reduced with $\mathrm{Cu}$ at $680^{\circ} \mathrm{C}$. The combustion products $\mathrm{N}_{2}$ and $\mathrm{CO}_{2}$ were introduced into a Delta C Finnigan MAT mass spectrometer through an $\mathrm{MgClO}_{4}$ drying column. The isotope ratio mass spectrometry facility at the Serveis Científico-Tècnics of the University of Barcelona (Spain) applies international standards, generally run for each 12 samples; IAEA $\mathrm{CH}_{7}(87 \%$ of C), IAEA $\mathrm{CH}_{6}(42 \%$ of C) and USGS $24(100 \%$ of C) for ${ }^{13} \mathrm{C}$ and IAEA $\mathrm{N}_{1}$ and IAEA $\mathrm{N}_{2}$ (with $21 \%$ of $\mathrm{N}$ ) and IAEA $\mathrm{NO}_{3}(13.8 \%$ of $\mathrm{N})$ for ${ }^{15} \mathrm{~N}$.

Statistical analyses. Data on the positions of birds tracked by geolocators were calculated using MultiTrace-3.16 light (Jensen Software Systems) by inspecting the integrity of the light curve day by day and fitting dawn and dusk times. To filter unrealistic positions, we removed those that had a velocity index $\left(V_{i}\right)$ above $50 \mathrm{~km} \mathrm{~h}^{-1}$, indicating an unlikely movement out and back from the normal track as defined by the preceding and following positions. The $V_{i}$ was calculated as the root of the square velocity average of the segments between the 2 preceding and the 2 following positions (see McConnell et al. 1992). By this procedure we discarded $7 \%$ of 755 positions. We calculated 3 feeding behaviour descriptors (foraging effort, maximum foraging range and feeding zones) for the 5 breeding stages defined. Foraging effort was calculated as the daily distance travelled on each breeding stage. We defined the foraging ground on each breeding stage as the area encompassing $50 \%$ of the filtered positions using kernel analysis (cylindrical-equivalent projection, cell size of $5000 \mathrm{~m}$ and smoothing factor of $200 \mathrm{~m})$. We used the Animal Movement Extension for ArcView 3.2 (Hooge \& Eichenlaub 1997) to perform kernel analyses.

To examine differences in physiological values of males and females over the breeding season we used a repeated measures ANOVA, including the breeding stages pre-laying, egg-laying, incubation and hatching, and sex as fixed factors. All variables were previously log-transformed to meet normality. When the interaction between sex and breeding stage was significant $(p<0.05)$ we repeated the analysis for each sex separately. To detect differences between breeding stages, we applied a post-hoc $t$-test using Bonferroni correction. Since the number of birds re-sampled during chick-rearing was lower than the other 4 stages, we first examined the 4 consecutive stages (pre-laying, egg-laying, incubation and hatching), and in a second analysis we compared hatching against chick-rearing periods. Finally, to examine relationships among physiological variables, we used linear mixed models. For each pair of physiological variables, one was considered as the independent variable and the other as covariable (e.g. triglyceride was the independent variable, whereas cholesterol was the co-variable). Among all possible relationships between variables, we only considered consistent relationships between sexes and throughout the breeding season, i.e. those pairs for which the co-variable did not show any significant interaction with sex or breeding stage. We used SPSS $12.0^{\circledR}$ for Windows ${ }^{\circledR}$ to perform all statistical analyses.

\section{RESULTS}

\section{Changes in foraging and feeding behaviour}

The principal feeding area changed from higher latitudes during the pre-laying and egg-laying stages to lower latitudes during the chick-rearing stage (Fig. 1). Foraging effort was greater during pre-laying and chickrearing in comparison with egg-laying, incubation and hatching (Fig. 2A). Maximum foraging range during the chick-rearing stage was greater than during the

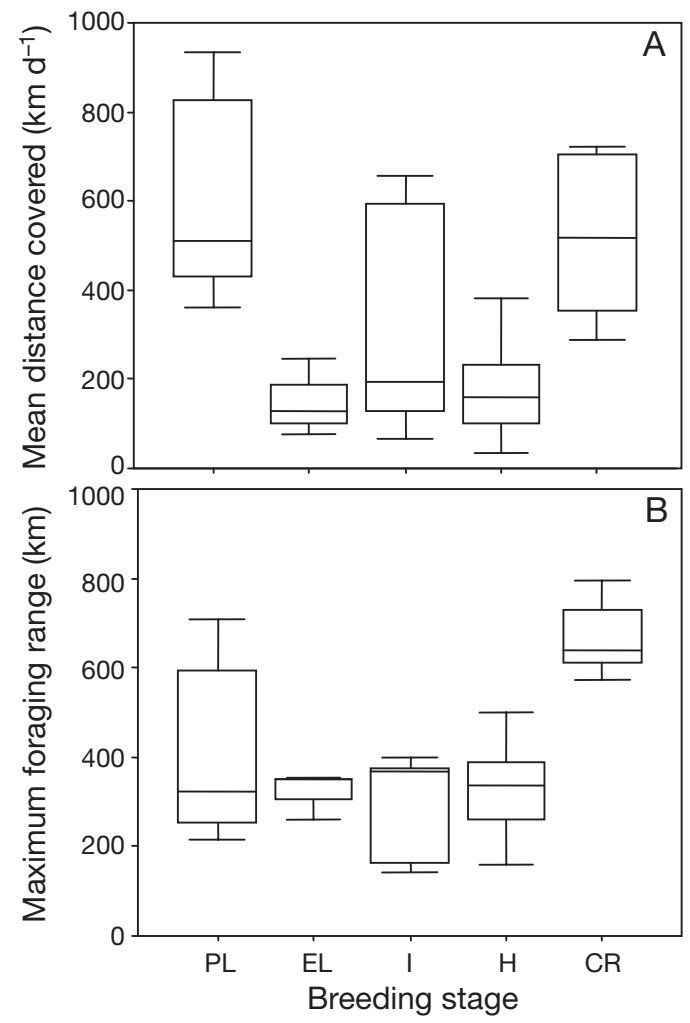

Fig. 2. Calonectris diomedea. Changes in foraging effort, as indicated by (A) mean daily distance covered and (B) maximum foraging range of 6 individuals tracked by geolocators throughout the 5 breeding stages (PL: pre-laying; EL: egglaying; I: incubation; H: hatching; and CR: chick-rearing). Box length represents interquartile range, bar length represents range and horizontal lines represent median values 
other stages (Fig. 2B). $\delta^{15} \mathrm{~N}$ signatures increased sharply between pre-laying and incubation, stabilized between incubation and hatching and decreased sharply (to close to the initial values) in both sexes between hatching and chick-rearing (Fig. 3A, Tables $1-3$ ). $\delta^{13} \mathrm{C}$ signatures increased sharply in both sexes between pre-laying and hatching (Fig. 3B, Tables 1-3).

\section{Changes in body mass and nutritional condition}

Body mass increased significantly between prelaying and hatching, and decreased to the prelaying levels in the chick-rearing period (Fig. 3C, Tables 1-3). In females, triglycerides first decreased sharply between pre-laying and egg-laying, and then increased between hatching and chick-rearing (Fig. 3D, Tables 1-3). Males showed a similar trend, except during the pre-laying period, when females had levels nearly 3 times higher than males. Cholesterol variation was similar to triglyceride variation, decreasing in both sexes between pre-laying and egg-laying and increasing between egg-laying and chick-rearing (Fig. 3E, Tables 1-3). Total protein decreased between pre-laying and egg-laying, and increased between egg-laying and hatching (Fig. 3F, Tables 1-3). Uric acid decreased between pre-laying and incubation, and increased sharply between incubation and chickrearing in both sexes (Fig. 3G, Tables 1-3). An opposite trend was found in urea; this metabolite increased between pre-laying and incubation and decreased between incubation and chick-rearing in both sexes (Fig. 3H, Tables 1-3).

\section{Changes in hematocrit and hemoglobin}

Hematocrit increased in a sustained manner between pre-laying and chick-rearing in females, whereas in males there was no trend except a transitory increase during the egg-laying stage (Fig. 3I, Tables 1 \& 3). As expected, a similar trend was observed in blood hemoglobin concentration, which significantly varied among breeding stages. Whereas
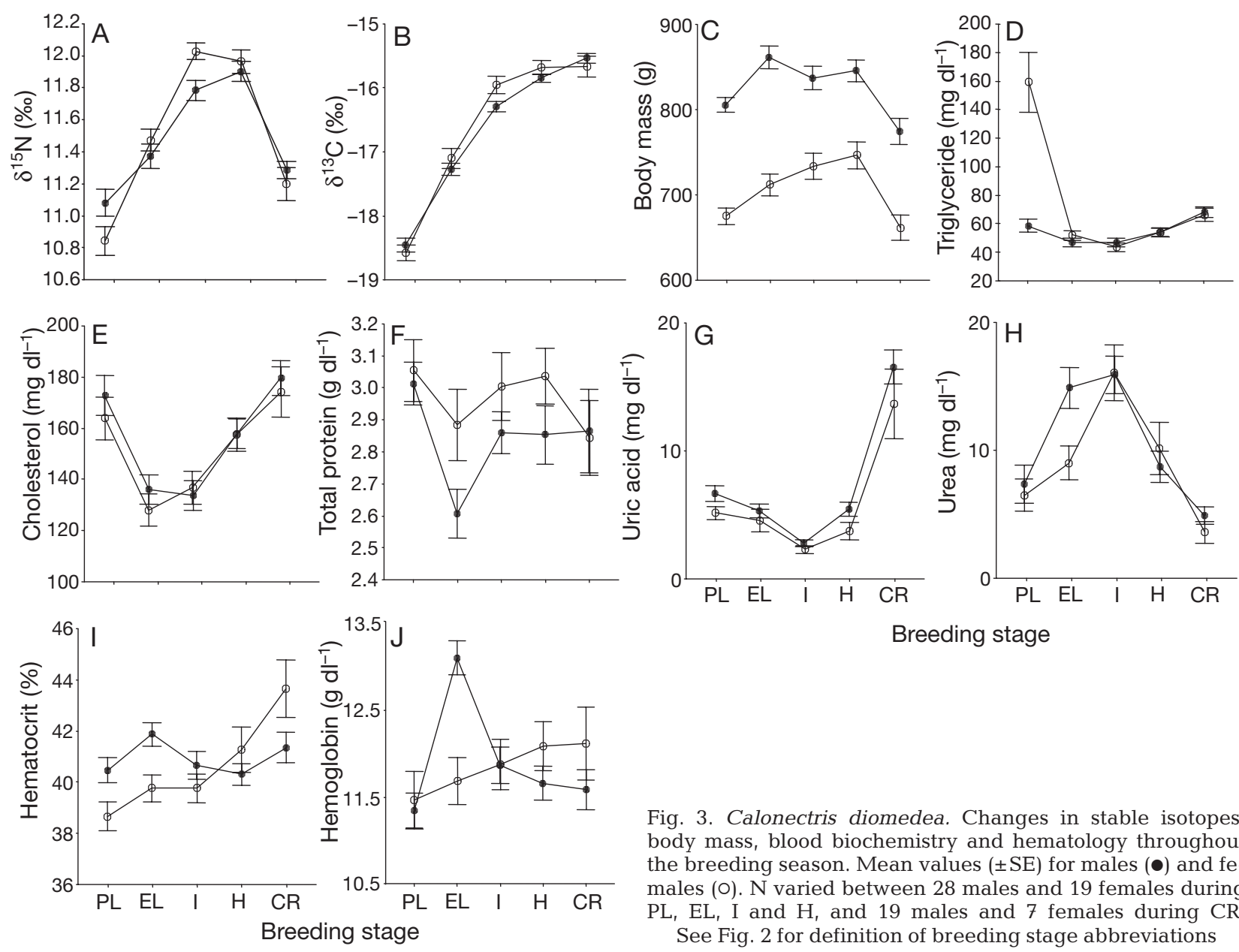

Breeding stage

Fig. 3. Calonectris diomedea. Changes in stable isotopes, body mass, blood biochemistry and hematology throughout the breeding season. Mean values $( \pm \mathrm{SE})$ for males $(\bullet)$ and females (O). N varied between 28 males and 19 females during PL, EL, I and $\mathrm{H}$, and 19 males and 7 females during CR. See Fig. 2 for definition of breeding stage abbreviations 
Table 1. Summary of repeated sample ANOVA tests examining variation in stable isotopes, body mass, blood biochemistry and hematology between stages for 28 male and 19 female Calonectris diomedea. PL: pre-laying; EL: egg-laying; I: incubation; $\mathrm{H}$ : hatching. Pairs of means differing significantly $(\mathrm{p}<0.05)$ by $t$-test are linked with an ' $\mathrm{X}$ '

\begin{tabular}{|c|c|c|c|c|}
\hline Parameter & Effect & $F_{[\mathrm{df}]}$ & $\mathrm{p}$ & Post-hoc $t$-test \\
\hline$\delta^{15} \mathrm{~N}(\%)$ & $\begin{array}{l}\text { Stage } \\
\text { Sex } \\
\text { Stage } \times \text { Sex } \\
\text { Stage (male) } \\
\text { Stage (female) }\end{array}$ & $\begin{array}{c}77.25_{[3,43]} \\
0.34_{[1,45]} \\
4.6_{[3,43]} \\
32.01_{[3,25]} \\
65.62_{[3,16]}\end{array}$ & $\begin{aligned}< & 0.001 \\
& 0.56 \\
& 0.01 \\
< & 0.001 \\
< & 0.001\end{aligned}$ & $\begin{array}{l}\mathrm{PL} \times \mathrm{EL}, \mathrm{I}, \mathrm{H}, \mathrm{EL} \times \mathrm{I}, \mathrm{H} \\
\mathrm{PL} \times \mathrm{EL}, \mathrm{I}, \mathrm{H}, \mathrm{EL} \times \mathrm{I}, \mathrm{H}\end{array}$ \\
\hline$\delta^{13} \mathrm{C}(\%)$ & $\begin{array}{l}\text { Stage } \\
\text { Sex } \\
\text { Stage } \times \text { Sex }\end{array}$ & $\begin{array}{c}289.07_{[3,43]} \\
2.34_{[1,45]} \\
1.41_{[3,43]}\end{array}$ & $\begin{array}{c}<0.001 \\
0.13 \\
0.25\end{array}$ & $\mathrm{PL} \times \mathrm{EL}, \mathrm{I}, \mathrm{H}, \mathrm{EL} \times \mathrm{I}, \mathrm{H}, \mathrm{I} \times \mathrm{H}$ \\
\hline Body mass (g) & $\begin{array}{l}\text { Stage } \\
\text { Sex } \\
\text { Stage } \times \text { Sex }\end{array}$ & $\begin{array}{c}13.37_{[3,43]} \\
72.85_{[1,45]} \\
2.43_{[3,43]}\end{array}$ & $\begin{array}{c}<0.001 \\
<0.001 \\
0.07\end{array}$ & $\mathrm{PL} \times \mathrm{EL}, \mathrm{I}, \mathrm{H}$ \\
\hline Triglycerides $\left(\mathrm{mg} \mathrm{dl}^{-1}\right)$ & $\begin{array}{l}\text { Stage } \\
\text { Sex } \\
\text { Stage } \times \text { Sex } \\
\text { Stage (male) } \\
\text { Stage (female) }\end{array}$ & $\begin{array}{c}18.81_{[3,43]} \\
24.93_{[1,45]} \\
10.05_{[3,43]} \\
2.65_{[3,25]} \\
14.14_{[3,16]}\end{array}$ & $\begin{aligned}< & 0.001 \\
< & 0.001 \\
< & 0.001 \\
& 0.07 \\
< & 0.001\end{aligned}$ & $\mathrm{PL} \times \mathrm{EL}, \mathrm{I}, \mathrm{H}, \mathrm{I} \times \mathrm{H}$ \\
\hline Cholesterol $\left(\mathrm{mg} \mathrm{dl}^{-1}\right)$ & $\begin{array}{l}\text { Stage } \\
\text { Sex } \\
\text { Stage } \times \text { Sex }\end{array}$ & $\begin{array}{c}18.88_{[3,43]} \\
0.3_{[1,45]} \\
0.43_{[3,43]}\end{array}$ & $\begin{array}{c}<0.001 \\
0.58 \\
0.73\end{array}$ & $\mathrm{PL} \times \mathrm{EL}, \mathrm{I}, \mathrm{H} \times \mathrm{EL}, \mathrm{I}$ \\
\hline Total protein $\left(\mathrm{g} \mathrm{dl}^{-1}\right)$ & $\begin{array}{l}\text { Stage } \\
\text { Sex } \\
\text { Stage } \times \text { Sex }\end{array}$ & $\begin{array}{l}4.53_{[3,43]} \\
3.34_{[1,45]} \\
0.77_{[3,43]}\end{array}$ & $\begin{array}{l}0.01 \\
0.07 \\
0.51\end{array}$ & $\mathrm{EL} \times \mathrm{H}, \mathrm{PL}$ \\
\hline Uric acid $\left(\mathrm{mg} \mathrm{dl}^{-1}\right)$ & $\begin{array}{l}\text { Stage } \\
\text { Sex } \\
\text { Stage } \times \text { Sex }\end{array}$ & $\begin{array}{c}24.63_{[3,43]} \\
6.66_{[1,45]} \\
0.35_{[3,43]}\end{array}$ & $\begin{array}{c}<0.001 \\
0.01 \\
0.46\end{array}$ & $\mathrm{PL} \times \mathrm{EL}, \mathrm{I}, \mathrm{H}, \mathrm{I} \times \mathrm{EL}, \mathrm{H}$ \\
\hline Urea $\left(\mathrm{mg} \mathrm{dl}^{-1}\right)$ & $\begin{array}{l}\text { Stage } \\
\text { Sex } \\
\text { Stage } \times \text { Sex }\end{array}$ & $\begin{array}{c}10.35_{[3,43]} \\
1.03_{[1,45]} \\
1.69_{[3,43]}\end{array}$ & $\begin{array}{c}<0.001 \\
0.31 \\
0.18\end{array}$ & $\begin{array}{l}\mathrm{PL} \times \mathrm{EL}, \mathrm{I} \\
\mathrm{I} \times \mathrm{H}\end{array}$ \\
\hline Hematocrit (\%) & $\begin{array}{l}\text { Stage } \\
\text { Sex } \\
\text { Stage } \times \text { Sex } \\
\text { Stage (male) } \\
\text { Stage (female) }\end{array}$ & $\begin{array}{l}3.33_{[3,43]} \\
2.71_{[1,45]} \\
3.94_{[3,43]} \\
5.31_{[3,25]} \\
1.73_{[3,16]}\end{array}$ & $\begin{array}{l}0.02 \\
0.11 \\
0.01 \\
0.01 \\
0.20\end{array}$ & $\mathrm{PL} \times \mathrm{EL}$ \\
\hline Hemoglobin $\left(\mathrm{g} \mathrm{dl}^{-1}\right)$ & $\begin{array}{l}\text { Stage } \\
\text { Sex } \\
\text { Stage } \times \text { Sex } \\
\text { Stage (male) } \\
\text { Stage (female) }\end{array}$ & $\begin{array}{c}9.99_{[3,43]} \\
0.72_{[1,45]} \\
11.98_{[3,43]} \\
43.14_{[3,25]} \\
0.81_{[3,16]}\end{array}$ & $\begin{array}{c}<0.001 \\
0.40 \\
<0.001 \\
<0.001 \\
0.51\end{array}$ & $\mathrm{EL} \times \mathrm{PL}, \mathrm{I}, \mathrm{H}$ \\
\hline
\end{tabular}

females showed a slight sustained increase, in males hemoglobin exhibited a sharp increase between the pre-laying and egg-laying stages but quickly decreased after egg-laying (Fig. 3J, Tables 1 \& 3).

\section{Sexual differences}

Only body mass and plasma concentration of triglycerides and uric acid were significantly different between sexes. Body mass and uric acid showed higher values in males, while triglyceride levels were higher in females (Table 1, see 'Sex' in the 'Effect' column).

\section{Association between physiological variables}

Among all pairs of physiological variables, we found consistent associations for both sexes throughout the breeding season in only 2 cases: between hematocrit and hemoglobin (Fig. 4A,B, $F_{1,199}=131.81$, p < 0.001) and between triglycerides and cholesterol (Fig. 4C,D, $\left.F_{1,199}=40.81, \mathrm{p}<0.001\right)$.

\section{DISCUSSION}

Cory's shearwaters changed their biochemical metabolites, body mass, hematological levels, feeding areas 
Table 2. Summary of repeated sample ANOVA tests examining variation in stable isotopes, body mass, blood biochemistry and hematology between hatching and chick-rearing periods for 19 male and 7 female Calonectris diomedea

\begin{tabular}{|c|c|c|c|}
\hline Parameter & Factor & $F_{[\mathrm{df}]}$ & $\mathrm{p}$ \\
\hline$\delta^{15} \mathrm{~N}(\%)$ & $\begin{array}{l}\text { Stage } \\
\text { Sex } \\
\text { Stage } \times \text { Sex }\end{array}$ & $\begin{array}{c}63.50_{[1,24]} \\
0.44_{[1,24]} \\
0.22_{[1,24]}\end{array}$ & $\begin{array}{c}<0.001 \\
0.51 \\
0.64\end{array}$ \\
\hline$\delta^{13} \mathrm{C}(\%)$ & $\begin{array}{l}\text { Stage } \\
\text { Sex } \\
\text { Stage } \times \text { Sex }\end{array}$ & $\begin{array}{l}1.23_{[1,45]} \\
0.09_{[1,45]} \\
3.98_{[1,45]}\end{array}$ & $\begin{array}{l}0.27 \\
0.76 \\
0.06\end{array}$ \\
\hline Body mass (g) & $\begin{array}{l}\text { Stage } \\
\text { Sex } \\
\text { Stage } \times \text { Sex }\end{array}$ & $\begin{array}{c}44.20_{[1,24]} \\
24.27_{[1,24]} \\
0.39_{[1,24]}\end{array}$ & $\begin{array}{c}<0.001 \\
<0.001 \\
0.54\end{array}$ \\
\hline Triglycerides $\left(\mathrm{mg} \mathrm{dl}^{-1}\right)$ & $\begin{array}{l}\text { Stage } \\
\text { Sex } \\
\text { Stage } \times \text { Sex }\end{array}$ & $\begin{array}{l}9.23_{[1,24]} \\
0.09_{[1,24]} \\
0.70_{[1,24]}\end{array}$ & $\begin{array}{l}0.01 \\
0.77 \\
0.41\end{array}$ \\
\hline Cholesterol $\left(\mathrm{mg} \mathrm{dl}^{-1}\right)$ & $\begin{array}{l}\text { Stage } \\
\text { Sex } \\
\text { Stage } \times \text { Sex }\end{array}$ & $\begin{array}{l}4.74_{[1,24]} \\
0.29_{[1,24]} \\
0.01_{[1,24]}\end{array}$ & $\begin{array}{l}0.04 \\
0.59 \\
0.93\end{array}$ \\
\hline Total protein $\left(\mathrm{g} \mathrm{dl}^{-1}\right)$ & $\begin{array}{l}\text { Stage } \\
\text { Sex } \\
\text { Stage } \times \text { Sex }\end{array}$ & $\begin{array}{l}0.70_{[1,24]} \\
0.02_{[1,24]} \\
0.23_{[1,24]}\end{array}$ & $\begin{array}{l}0.41 \\
0.89 \\
0.64\end{array}$ \\
\hline Uric acid $\left(\mathrm{mg} \mathrm{dl}^{-1}\right)$ & $\begin{array}{l}\text { Stage } \\
\text { Sex } \\
\text { Stage } \times \text { Sex }\end{array}$ & $\begin{array}{c}40.24_{[1,24]} \\
1.56_{[1,24]} \\
0.45_{[1,24]}\end{array}$ & $\begin{array}{c}<0.001 \\
0.22 \\
0.51\end{array}$ \\
\hline Urea $\left(\mathrm{mg} \mathrm{dl}^{-1}\right)$ & $\begin{array}{l}\text { Stage } \\
\text { Sex } \\
\text { Stage } \times \text { Sex }\end{array}$ & $\begin{array}{l}0.56_{[1,24]} \\
0.03_{[1,24]} \\
0.58_{[1,24]}\end{array}$ & $\begin{array}{l}0.01 \\
0.87 \\
0.45\end{array}$ \\
\hline Hematocrit (\%) & $\begin{array}{l}\text { Stage } \\
\text { Sex } \\
\text { Stage } \times \text { Sex }\end{array}$ & $\begin{array}{l}4.99_{[1,24]} \\
3.87_{[1,24]} \\
0.07_{[1,24]}\end{array}$ & $\begin{array}{l}0.03 \\
0.06 \\
0.79\end{array}$ \\
\hline Hemoglobin $\left(\mathrm{g} \mathrm{dl}^{-1}\right)$ & $\begin{array}{l}\text { Stage } \\
\text { Sex } \\
\text { Stage } \times \text { Sex }\end{array}$ & $\begin{array}{l}0.15_{[1,24]} \\
2.04_{[1,24]} \\
0.02_{[1,24]}\end{array}$ & $\begin{array}{l}0.70 \\
0.16 \\
0.88\end{array}$ \\
\hline
\end{tabular}

indicating a progressive shift from more pelagic and more northern waters during pre-laying (low signatures) to more neritic and more southern areas during chick-rearing (high signatures) (Hobson et al. 1994, Thompson et al. 2000, Gómez-Díaz \& González-Solís 2007).

Nitrogen signatures $\left(\delta^{15} \mathrm{~N}\right)$ also showed small but significant changes over the season. In particular, $\delta^{15} \mathrm{~N}$ were low during pre-laying and chickrearing periods, and high from egglaying to hatching (Fig. 3A). We interpreted these changes as a variation in the diet throughout breeding season (see Forero \& Hobson 2003). In particular, the diet of shearwaters during incubation was richer in protein (high $\delta^{15} \mathrm{~N}$ ) than during pre-laying and chick-rearing (low $\delta^{15} \mathrm{~N}$ ). These changes could be related to changes in the availability of prey or in the protein/lipid requirements during breeding. An alternative interpretation of the observed variation could be the catabolism of protein stores during fasting stints while incubating. Cherel et al. (2005) found enrichment in $\delta^{15} \mathrm{~N}$ signatures during the fasting period in the king penguin Aptenodytes patagonicus and suggested that during periods of food deprivation, animals 'feed on themselves,' increasing the apparent trophic level.

In parallel with changes in foraging areas and parental duties, foraging effort also changed seasonally, being greater at the onset and end of the breeding season (Fig. 2). During incubation, birds spent approximately half of the time on the nest and foraged close to the breeding colony, whereas during the pre-laying and chick-rearing periods, birds foraged in more distant areas and for longer periods. That is, during incubation, birds maximize time at sea, whereas during pre-laying and chick-rearing periods foraging effort increases because birds increase the rate of visits to the nests (Ricklefs 1983, Grau 1984, Shaffer et al. 2003).

Body mass increased from pre-laying to hatching (more obviously in females) but decreased to the prelaying levels during the chick-rearing period (Fig. 3C, Tables 1-3). These mass oscillations could be interpreted as an intrinsic process referred to as 'programmed anorexia,' a means to achieve lower cost of foraging through decreased flight cost (Mrosovsky \& Sherry 1980, Freed 1981, Norberg 1981, Moe et al. 


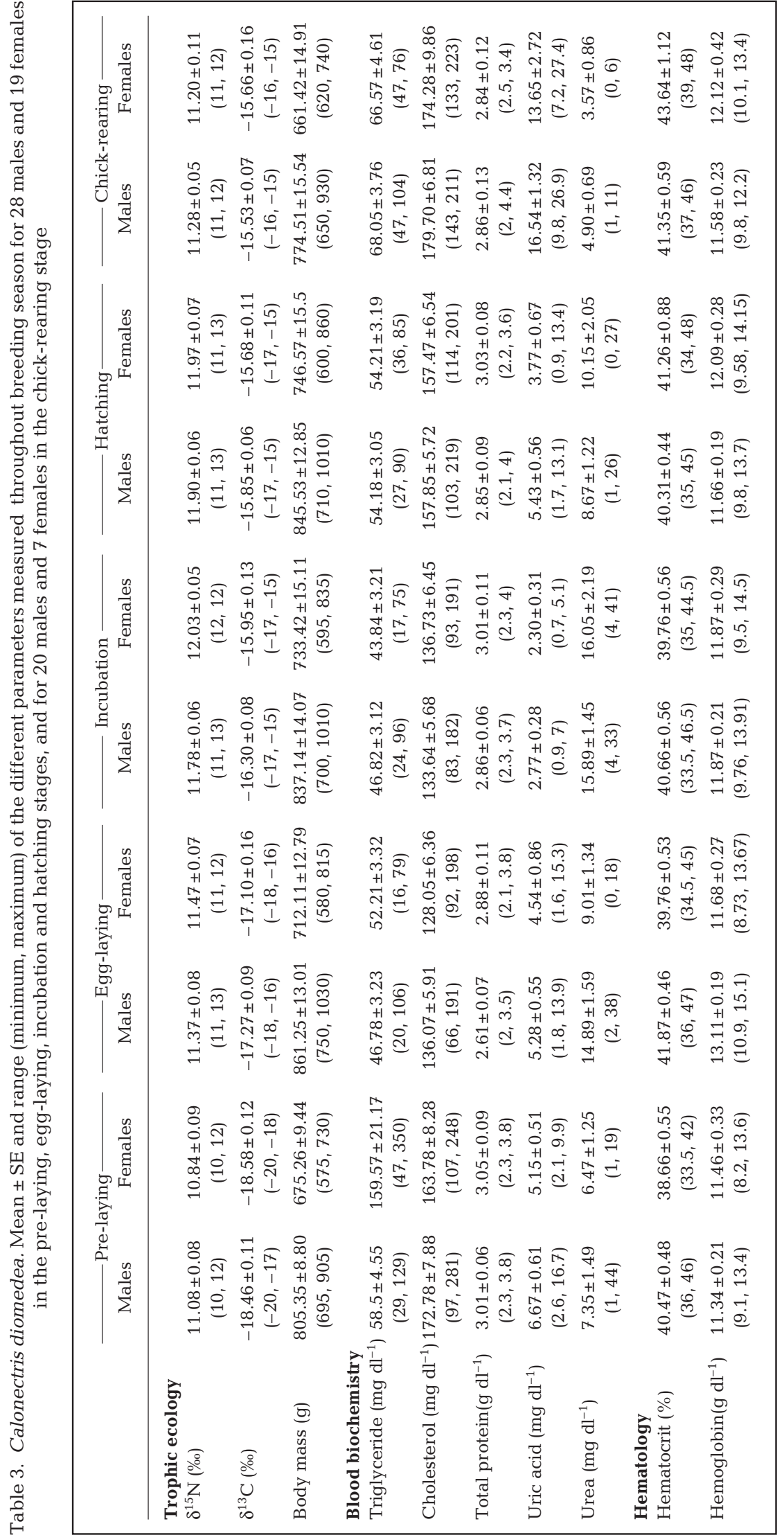

2002). Flight cost is highly dependent on body mass and lower mass values during pre-laying and chickrearing could substantially reduce the cost of a greater foraging effort during these stages (Fig. 2). Furthermore, greater lipid stores during incubation are probably related to incubation behaviour. Petrels have long incubation periods, with males and females alternating incubation and foraging, typically in shifts lasting $1 \mathrm{wk}$ or more while the partner fasts on the nest. Since the decision to cease incubation and start selffeeding is usually subordinate to relief by the partner, greater fat stores during incubation would increase fasting endurance and prevent temporary abandonment of the egg, avoiding egg cooling or nest predation.

The increase found in urea values in incubating Cory's shearwaters could be related to protein catabolism during the fasting stints, since birds may run out of lipid reserves and obtain metabolic energy from proteins (Totzke et al. 1999, Whittow 2000). Indeed, when urea levels were high, triglyceride levels were low. This relationship, particularly strong at egg-laying and hatching, also seems to indicate an increase in the use of proteins to obtain metabolic energy during fasting stints once lipid reserves have been exhausted. Uric acid also indicates protein catabolism (Jenni-Eiermann \& Jenni 1998), but in our study it showed opposite patterns to urea levels, with lower values between the pre-laying and incubation stages and greater values between the incubation and chick-rearing stages (Fig. 3H). This contrasting pattern may respond to different pathways of uric acid compared to urea in response to an increase in the flying activity during pre-laying and chickrearing stages. Apparently, uric acid tends to increase during endurance flight as a consequence of the use of protein as a metabolic resource (Jenni et al. 2000). 

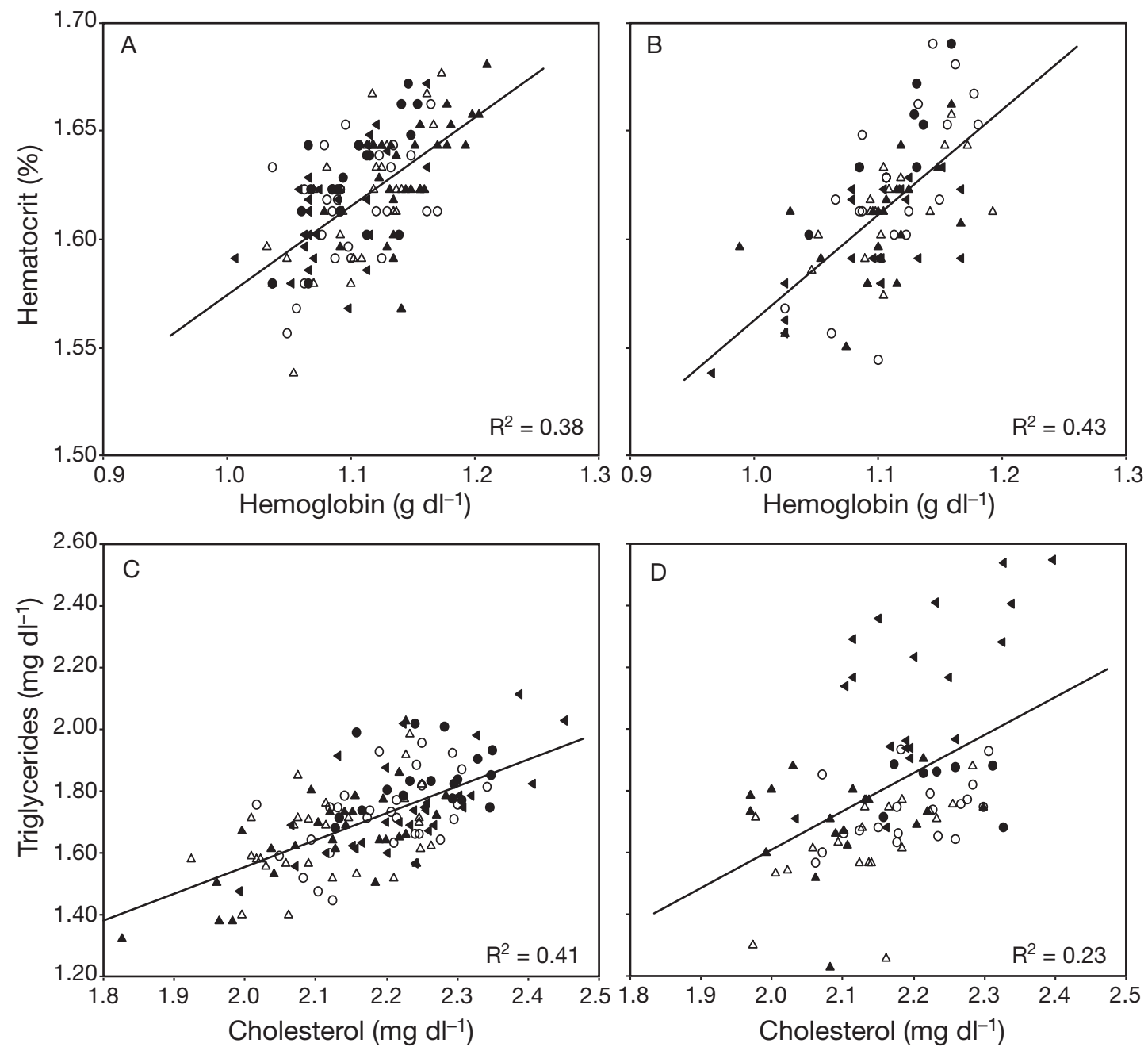

$\triangleleft$ Pre-laying $\Delta$ Egg-laying $\Delta$ Incubation $\circ$ Hatching $\bullet$ Chick-rearing

Fig. 4. Calonectris diomedea. Relationships between $(\mathrm{A}, \mathrm{B})$ hematocrit and hemoglobin and $(\mathrm{C}, \mathrm{D})$ triglyceride and cholesterol for $(A, C)$ males and $(B, D)$ females throughout the breeding season. All variables were log transformed

An increase in foraging effort could result in the increase of hematocrit and hemoglobin values, since these parameters have been regarded as an index of aerobic metabolic activity (Carpenter 1975). A recent study on Cory's shearwaters supports this relationship, since an experimental increase in foraging effort tended to increase hematocrit levels (Navarro \& González-Solís 2007). In the present study, hematocrit and hemoglobin certainly showed a similar response throughout the breeding season (Fig. 4A,B). However, the relationship between hematocrit and foraging effort was only apparent at the chick-rearing stage, not at pre-laying, when foraging effort was actually greatest in both stages (Figs. 2 \& 3I,J). The association between foraging effort and hematological values in the pre-laying stage may be obscured by the role of sexual hormones. High concentrations of sexual hor- mones and the presence of egg-yolk precursors in the blood during this stage could produce a decrease in the hematological values (Whittow 2000, Williams et al. 2004). After that period, hematological values in both males and females recovered to their normal levels. Animals can also increase their hematocrit by dehydrating while fasting (Morton 1994), but in the present study all birds were sampled at the first day of the incubation bout.

One of the most energy-demanding activities over the annual cycle of many bird species is migration. Cory's shearwaters are long-distance migrants, most of them making transequatorial movements totaling between 15000 and $35000 \mathrm{~km}$ during winter (González-Solís et al. 2007). After such effort, birds have to recover physiologically, as well as to prepare for the next migration period at the end of the breeding sea- 
son (Blem 1980, Ramenofsky 1990). In both cases, birds must increase their fat stores (Lindström \& Piersma 1993). An indication of this: triglyceride and cholesterol metabolites, 2 indicators of lipid mobilization (Jenni-Eiermann \& Jenni 1998), showed a positive relation and tended to increase after arrival (pre-laying) and before migration departure (chick-rearing) (Fig. 3D,E). In addition to recovering from migration, females need to obtain lipids during the pre-laying stage to form the egg yolk (Vanderkist et al. 2000, Williams 2005). Accordingly, females showed an exceptionally high level of triglyceride (Fig. 3D), which is an indicator of egg formation (Vanderkist et al. 2000). This was further corroborated by the drop in triglycerides between the pre-laying and egg-laying stages observed in females only (Fig. 3D).

\section{CONCLUSIONS}

Movements tracked with geolocators and stable isotope signatures indicated seasonal changes in feeding grounds and foraging effort, which ultimately influenced oxygen carrying capacity. Body mass and plasma metabolites were associated with temporal changes in nutritional state, in relation to egg formation, fasting, chick provisioning and recovery after migration. This study illustrates the influence of main breeding duties on nutritional and feeding ecology and underlines the need for more integrative approaches in the ecophysiology of wild birds.

Acknowledgements. We thank A. Pastor, S. García, R. Ramos and M. Soria for their field support; P. Calabuig (Cabildo de Gran Canaria) and Y. Amescoa for their logistical support; A. Kaliontzopoulou for revision of the English; L. Jover and $\mathrm{X}$. Ruiz for their help on different aspects; and 3 anonymous referees for their helpful comments. J. Navarro was supported by a postgraduate grant from the Ministerio de Educación y Ciencia (MEyC) of Spain and J. González-Solís was supported by a contract of the Program Ramon y Cajal funded by the MEyC and Fondos FEDER. Financial support was provided by the projects REN2002-01164/GLO and 2005GR 00744, and the Fundación Banco Bilbao Vizcaya-Argentaria (FBBVA 2005).

\section{LITERATURE CITED}

Afanasyev V (2004) A miniature daylight level and activity data recorder for tracking animals over long periods. Mem Natl Inst Polar Res (Spec Issue) 58:227-233

Alonso-Álvarez C, Velando A, Ferrer M, Veira JAR (2002) Changes in plasma biochemistry and body mass during incubation in the Yellow-legged Gull. Waterbirds 25: 253-258

Barton ED, Arístegui J, Tett P, Cantón M and others (1998) The transition zone of the Canary Current upwelling region. Prog Oceanogr 41:455-504
Blem CR (1980) The energetics of migration. In: Gauthreaux SA (ed) Animal migration, orientation, and navigation. Academic Press, New York, p 175-224

Bordel R, Haase E (1993) Effects of flight on blood parameters in homing pigeons. J Comp Physiol 163:219-224

Bridge EL (2006) Influences of morphology and behaviour on wing-molt strategies in seabirds. Mar Ornithol 34:7-19

Brooke M (2004) Albatrosses and petrels across the world. Oxford University Press, Oxford

Bustamante J, Traviani A (1994) Effect of keeping plasma at $-20^{\circ} \mathrm{C}$ on the concentration of blood metabolites. Comp Biochem Physiol Part A 107:661-664

Carpenter FL (1975) Bird hematocrit: effects of high altitude and strength of flight. Comp Biochem Physiol Part A 50: 415-417

Cherel Y, Hobson KA, Bailleul F, Groscolas R (2005) Nutrition, physiology, and stable isotopes: new information from fasting and molting penguins. Ecology 86:2881-2888

Davenport R, Neuer S, Helmke P, Perez-Marrero J, Llinas O (2002) Primary productivity in the northern Canary Islands region as inferred from SeaWiFS imagery. Deep-Sea Res 49:3481-3496

DeNiro MJ, Epstein S (1981) Influence of diet on the distribution of nitrogen isotopes in animals. Geochim Cosmochim Acta 45:341-351

Drabkin DL, Austin JH (1936) Spectrophotometric studies. V.A. technique for the analysis of undiluted blood and concentrated hemoglobin solution. J Biol Chem 112: $105-115$

Forero MG, Hobson KA (2003) Using stable isotopes of nitrogen and carbon to study seabird ecology: applications in the Mediterranean seabird community. Sci Mar 67:23-32

Freed LA (1981) Loss of mass in breeding wrens: stress or adaptation? Ecology 62:1179-1186

Gómez-Díaz E, González-Solís J (2007) Geographic assignment of seabirds to their origin: combining morphologic, genetic, and biochemical analyses. Ecol Appl 17:1484-1498

González-Solís J, Croxall JP, Oro D, Ruiz X (2007) Transequatorial migration and mixing in the wintering areas of a pelagic seabird. Front Ecol Environ 5:297-301

Grau CR (1984) Egg formation. In: Whittow GC, Rahn H (eds) Seabird energetics. Plenum Press, New York, p 33-57

Hobson KA, Piatt JF, Pitocchelli J (1994) Using stable isotopes to determine seabird trophic relationships. J Anim Ecol 63: 786-798

Hooge PN, Eichenlaub B (1997) Animal movement extension to ArcView, version 1.1. US Geological Survey, Anchorage, AK

Horak P, Jenni-Eirmann I, Tegelman L (1998) Health and reproduction: the sex-specific clinical profile of great tits (Parus major) in relation to breeding. Can J Zool 76: 2235-2244

Igual M, Forero MG, Tavecchia G, González-Solís J, Martínez-Abraín A, Hobson KA, Ruiz X, Oro D (2005) Short term effects of data-loggers on Cory's shearwater (Calonectris diomedea). Mar Biol 146:619-624

Jenni L, Jenni-Eiermann S, Spina S, Schwabl H (2000) Regulation of protein breakdown and adrenocortical response to stress in birds during migratory flight. Am J Physiol-Reg I 278:1182-1189

Jenni-Eiermann S, Jenni L (1991) Metabolic responses to flight and fasting in night migrating passerines. J Comp Physiol 161:465-474

Jenni-Eiermann S, Jenni L (1998) What can plasma metabolites tell us about metabolism, physiological state and condition of individual birds? An overview. Biol Conserv Fauna 102:312-319 
Jenni-Eiermann S, Jenni L, Piersma T (2002) Plasma metabolites reflect seasonally changing metabolic processes in a long-distance migrant shorebird. Zoology 105:239-246

Lindström A, Piersma T (1993) Mass changes in migrating birds: the evidence of fat and protein storage re-examined. Ibis 135:70-78

Longhurst A (1998) Ecological geography of the sea. Academic Press, San Diego, CA

McConnell BJ, Chambers C, Fedak MA (1992) Foraging ecology of southern elephant seals in relation to the bathymetry and productivity of the Southern Ocean. Antarct Sci 4:393-398

Moe B, Langseth I, Fyhn M, Gabrielsen GW, Bech C (2002) Changes in body condition of breeding kittiwakes Rissa tridactyla. J Avian Biol 33:225-234

Morton ML (1994) Hematocrits in montane sparrows in relation to reproductive schedule. Condor 96:119-126

Mrosovsky N, Sherry DF (1980) Animal anorexias. Science 207:837-842

Navarro J, González-Solís J (2007) Experimental increase of flying costs in a pelagic seabird: effects on foraging strategies, nutritional state and chick condition. Oecologia 151: 150-160

Norberg RA (1981) Temporary weight decrease in breeding birds may result in more fledged young. Am Nat 118: 838-850

Phillips RA, Silk JRD, Phalan B, Catry P, Croxall JP (2004) Seasonal sexual segregation in the two Thalassarche albatross species: competitive exclusion, reproductive role specialization or foraging niche divergence? Proc R Soc Lond B Biol Sci 271:1283-1291

Piersma T, Everaarts JM, Jukema J (1996) Build-up of red blood cells in refuelling bar-tailed godwits in relation to individual migratory quality. Condor 98:363-370

Editorial responsibility: Rory Wilson (Contributing Editor), Swansea, UK
Ramenofsky M (1990) Fat storage and fat metabolism in relation to migration. In: Gwinner E (ed) Bird migration. Springer, Berlin, p 214-231

Ricklefs RE (1983) Some considerations on the reproductive energetics of pelagic seabirds. Stud Avian Biol 8:84-94

Shaffer SA, Costa DP, Weimerskirch H (2003) Foraging effort in relation to the constraints of reproduction in freeranging albatrosses. Funct Ecol 17:66-74

Thibault JC, Bretagnolle V, Rabouam C (1997) Cory's shearwater. Birds of the Western Palearctic (BWP) Update, Oxford University Press, Oxford, p 75-98

Thompson DR, Phillips RA, Stewart FM, Waldron S (2000) Low $\delta^{13} \mathrm{C}$ signatures in pelagic seabirds: lipid ingestion as a potential source of ${ }^{13} \mathrm{C}$-depleted carbon in the Procellariiformes. Mar Ecol Prog Ser 208:265-271

Totzke U, Fenske M, Hüppopp O, Raabe H, Schach N (1999) The influence of fasting on blood and plasma composition of Herring Gulls (Larus argentatus). Physiol Biochem Zool 72:426-437

Vanderkist BA, Williams TD, Bertram DF, Lougheed LW, Ryder JL (2000) Indirect, physiological assessment of reproductive state and breeding chronology in free-living birds: an example in the Marbled murrelet (Brachyramphus marmoratus). Funct Ecol 14:758-765

Warham J (1990) The petrels: their ecology and breeding systems. Academic Press, London

Whittow GC (2000) Sturkie's avian physiology. Academic Press, New York

Williams TD (2005) Mechanisms underlying the costs of egg production. BioScience 55:39-48

Williams TD, Challenger WO, Christians JK, Evanson M, Love O, Vezina F (2004) What causes the decrease in haematocrit during egg production? Funct Ecol 18: $330-336$

Submitted: February 5, 2007; Accepted: June 20, 2007

Proofs received from author(s): November 5, 2007 